\title{
Smart Farming Technologies in Arable Farming: Towards a Holistic Assessment of Opportunities and Risks
}

\author{
Sebastian Lieder *(D) and Christoph Schröter-Schlaack \\ Department of Economics, Helmholtz-Centre for Environmental Research-UFZ, 04318 Leipzig, Germany; \\ christoph.schroeter-schlaack@ufz.de \\ * Correspondence: sebastian.lieder@ufz.de
}

Citation: Lieder, S.;

Schröter-Schlaack, C. Smart Farming Technologies in Arable Farming: Towards a Holistic Assessment of Opportunities and Risks.

Sustainability 2021, 13, 6783

https://doi.org/10.3390/su13126783

Academic Editor: Claus G. Sørensen

Received: 31 May 2021

Accepted: 14 June 2021

Published: 15 June 2021

Publisher's Note: MDPI stays neutral with regard to jurisdictional claims in published maps and institutional affiliations.

Copyright: (c) 2021 by the authors. Licensee MDPI, Basel, Switzerland. This article is an open access article distributed under the terms and conditions of the Creative Commons Attribution (CC BY) license (https:// creativecommons.org/licenses/by/ $4.0 /)$.

\begin{abstract}
Agricultural production finds itself in an area of tension. As a critical infrastructure, it has the task of reliably feeding a growing global population and supplying it with energy. However, the negative environmental impacts caused by agriculture, such as the global loss of biodiversity and the emission of greenhouse gases, are to be reduced. The increasing use of digital technologies is often described as a panacea that enables sustainable agriculture. The relevant literature is very dynamic, but the large number of concepts and terminologies used makes it difficult to obtain an overall view. In addition, many contributions focus on presumed or modeled efficiency gains, but this ignores technical and societal prerequisites and barriers. Therefore, the aim of this work was to identify the opportunities and risks of smart farming (SF) for more ecological arable farming. For this purpose, a holistic and environmental view was taken. The potential of SF to aid in the reduction in the environmental impacts of individual agricultural work steps was examined via an analysis of current literature. In addition, rebound effects, acceptance barriers and political omissions were considered as risks that prevent the benefits from being realized. It was shown that SF is able to contribute to a significant reduction in the negative environmental effects of agriculture. In particular, a reduction in fertilizer and pesticide application rates through mapping, sensing and precise application can lead to environmental benefits. However, achieving this requires the minimization of existing risks. For this reason, a proactive role of the state is required, implementing the necessary governance measures.
\end{abstract}

Keywords: smart farming; precision farming; sustainable agriculture

\section{Introduction}

Agriculture in the 21st century must be both resource efficient and sustainable in order to ensure a high level of food security and a reliable supply of renewable energy and materials for a growing global population. Currently, approximately $12 \%$ of global land area is used for crop production [1]. Technological innovations, increasing demand for agricultural products, limited (and in some cases declining) availability of arable land, water scarcity, and climate change have led to an intensification of agricultural production [2]. However, this intensification has resulted in significant damage to global environmental assets. In addition to emitting carbon dioxide, agriculture emits large amounts of the greenhouse gases such as nitrous oxide and methane, which are significantly more harmful to the climate [3]. Land use changes related to agriculture, such as deforestation or drainage of peatlands, are a major threat to biodiversity and also cause the emission of greenhouse gases [4,5]. The use of synthetic fertilizers and pesticides contaminates soil as well as water bodies and can result in nutrient runoff as well as the emission of air pollutants, such as ammonia [6,7]. Together with other factors, such as a reduction in field margins, the spread of monoculture, and the narrowing of crop rotations, this leads to long-term environmental damage and global biodiversity loss [4]. It is estimated that agriculture and forestry are responsible for almost $60 \%$ of global biodiversity loss [4]. This also leads to reduction and loss of valuable ecosystem services on which agricultural production depends, e.g., 
pollination, biological pest control, water retention and purification, maintenance of soil structure and fertility, and nutrient cycling [6,8].

Agriculture has already undergone numerous changes that have led to a significant transformation of its production steps. The introduction of smart systems such as the Internet of Things, Big Data, artificial intelligence, cloud computing, and other related technologies is now being characterized as the fourth revolution in agricultural production $[9,10]$. In contrast to other sectors, digital technologies have been used commercially in agriculture since the 1990s [11], with some technologies such as remote sensing applications since the 1980s [12]. The digitalization of all production areas, however, is now expected to enable the technical optimization of agricultural production systems, value chains and food systems, thereby also enabling a reduction in its environmental impacts [13,14]. This use of information and data-based technologies for collection, analysis, and application in agriculture is referred to as smart farming (SF) [15].

SF technology providers in particular, but increasingly also politicians, describe SF as a panacea in terms of efficiency and sustainability to agriculture of the future [16-18]. The growing but heterogeneous literature on the subject [19] also indicates this positive tendency. Thus, some reviews of SF technologies can be found in the literature and quite predominantly studies of individual software or hardware solutions. Methodologically, the existing literature focuses mainly on empirical surveys of effectiveness or technical considerations; technological feasibility is typically expressed as the maturity of a particular technology, the so-called technology readiness level (TRL) $[17,20]$. When the social, institutional and legal environment of SF technologies is considered, the focus is often on concrete barriers to acceptance and farmers' problems in applying them [21-26]. Holistic analysis of $\mathrm{SF}$ technologies that consider the opportunities but also the obstacles of implementation as a whole are hardly to be found in the scientific literature, and socio-cultural dimensions in particular are neglected in feasibility assessments [27]. Moreover, environmental risks associated with SF either due to rebound effects or to barriers for technology adoption are hardly considered in current research. There is also rarely a focus on arable farming, which shows clear differences from other forms of agricultural cultivation. This is somewhat surprising, because SF technologies are particularly relevant here due to the significant size of land take and hence related impact on soils, water bodies and the associated biodiversity.

In order to substantiate the alleged positive ecological effects, a holistic assessment is needed that takes into account the complex interactions between production technology, environmental impacts as well as socio-technical, behavioral and governance aspects of technology adoption, i.e, in addition to the undoubted technological potential of SF, necessary accompanying technical infrastructures as well as market conditions, regulatory settings and farmers' behavior that act as implementation barriers and prevent or slow down the application of SF technologies must be considered. This is crucial to derive the policy recommendation to realize the (environmental) potential of SF.

Against this background, the aim of this paper is twofold. First, we provide a literaturebased overview of SF technologies at individual stages of arable farming that include current and future opportunities (see Section 3) as well as associated environmental risks of SF technologies (see Section 4) based on a framework presented in Section 2. Secondly, we draw governance implications to realize the opportunities while minimizing environmental risks of SF technologies (see Section 5).

\section{Materials and Methods}

Relevant publications were identified by searching the online databases Web of Science and Google Scholar. Articles were included if they described single or multiple aspects of SF, such as digital technologies to reduce negative environmental impacts from arable farming, barriers to adoption of SF technologies, or rebound effects of digitalization. Publications up to the end of August 2020 were considered. However, the most important method was examining the references of relevant articles (snowballing). On the one hand, this is due to the numerous terminologies used in the literature to describe digital technologies 
in agriculture (e.g., SF, digital farming, and precision farming). In particular, the term precision farming is widely used in the scientific literature. We understand SF and precision farming as synonyms. However, in order to ensure consistency and clarity of the article, we are using SF as an umbrella term for the various terms used in the literature in the further course of the paper. Due to the lack of scientific publications directly linking SF to environmental impacts, gray literature was also included in the analysis.

To make it easier to understand our results, the opportunities of SF are presented with regard to the individual work steps of arable farming (see Section 3). After an introductory section explaining technologies relevant to several work steps, sub-chapters on crop rotation and cultivation planning, tillage and sowing, fertilization, crop protection, irrigation and harvesting follow. For each step of arable farming, negative environmental impacts and relevant SF technologies that can have a beneficial effect are identified. This is supplemented by selected empirical examples that prove an improvement in environmental impact.

With regard to environmental risks associated with SF, we distinguish between direct and indirect risks. Direct risks are due to rebound effects that outweigh positive environmental effects of SF technologies, such as energy consumption, increasing intensification of agriculture on marginal lands, or increasing irrigation. However, the sole consideration of rebound effects neglects other factors that also determine whether SF technologies will lead to the positive environmental impacts discussed in the literature. We therefore also include indirect risks that prevent the adoption of SF technologies and thus the realization of their positive effects, such as the technical, infrastructural requirements, gaps in the regulatory regime or acceptance barriers on the part of farmers. Especially the latter approach, which examines user barriers to acceptance, is common in recent technology assessment [28-30]. Our holistic approach allows a more realistic view of the potential of $\mathrm{SF}$ technologies, but also enables the derivation of policy measures to reduce such barriers for technology adoption. Based on studies of technology implementation [26,31-33], we derive a categorization of factors that may prevent the adoption of SF.

Figure 1 illustrates our approach that also provides the structure for the results presented in the following sections.

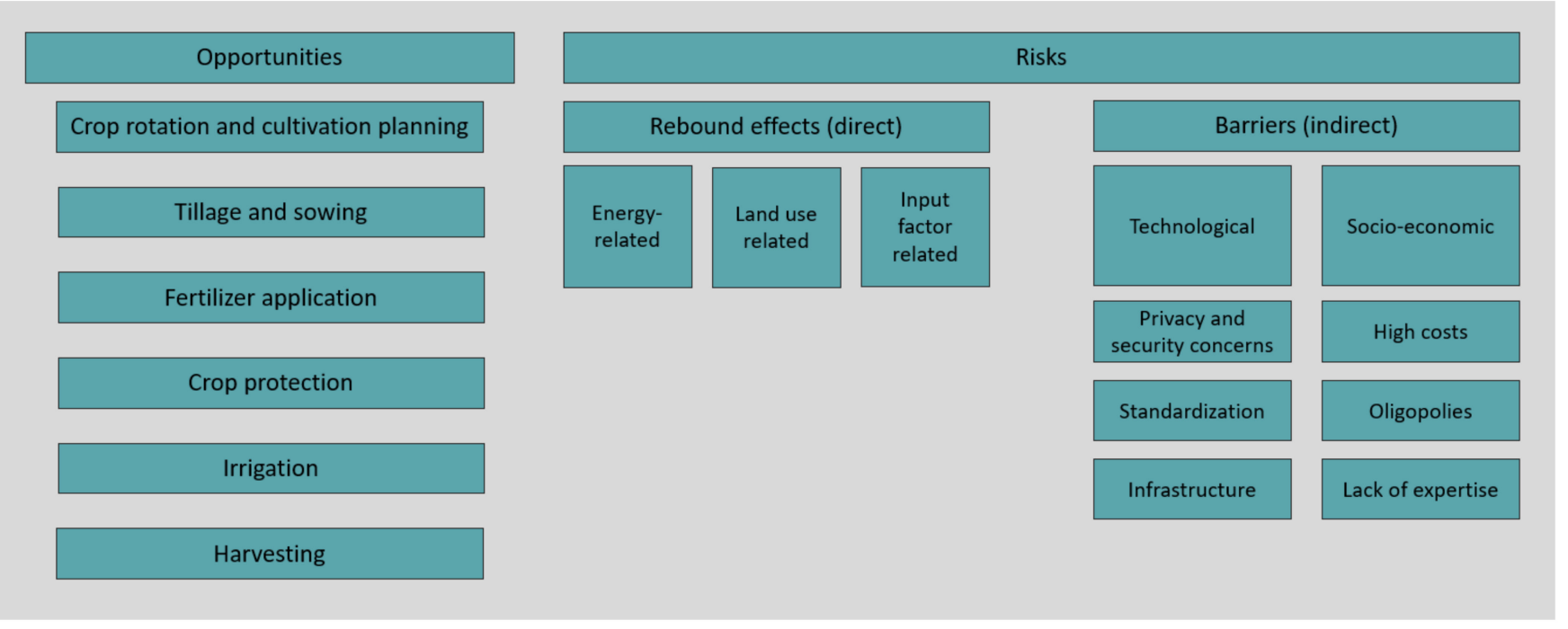

Figure 1. Overview of the opportunities and risks found through the evaluation.

\section{Opportunities of SF Technologies}

Before we go into detail on SF technologies for individual work steps in arable farming, we first point out some basic technologies that are relevant for several work steps or that are fundamental for further specific technologies. These include field mapping services, 
the deployment of small-scale autonomous machines, digital decision support systems or the use of digital forms of agricultural consultancy and administrative enforcement.

The extensive collection and comprehensive use of data to produce field mapping promises significant efficiency gains in crop production, resulting in both economic and environmental benefits [11]. The Talking Fields services are one example which offer different mapping methods that can contribute to better plant use of nutrients and water and thus to a reduction in input quantities [34]. Yield maps are another example which predict crop yields for individual subplots based on weather, climate and remote sensing data as well as growth models. In a survey of Australian grain farmers conducted by Bramley and Ouzman [35], the availability of yield maps was identified as a basic requirement for the adoption of other technologies such as crop and soil sensors for subplot specification. Accurate mapping is also crucial for a networked use of machines and robots performing site-specific tillage. Communication between large machines and digital control reduce greenhouse gas emissions in addition to time, as significant amounts of fuel are saved [36]. This is especially due to the use of optimal routes [37] and the prevention of overlaps, for example when applying crop protection products [38]. GPS control and driving of predefined routes can also be used for targeted exclusion of critical regions, for example to protect amphibian migration or accurate spacing from marginal and/or flower strips. The latter increase natural pest control and have positive effects on biodiversity and other ecosystem services [39-41].

Small-scale robots are increasingly taking over tasks and are significantly lighter than large machines, which reduces the risk of soil compaction and energy demand due to a small rolling resistance and also enables new farming methods, such as spot farming. However, a single mobile unit can only be practical to a limited extent, as it has too little energy to cover large fields. A fleet of robots to perform work and collect data is better as there is less risk of failure as the remaining robots continue to work even if one fails and the number of robots can be scaled to the size of the operation [42,43]. However, most models are still in the development phase. While the results to date are positive from an ecological perspective, economic relevance will not be achieved until costs are reduced. In the medium term, however, a significant increase in supply and market penetration can be assumed [44].

Computer-based decision support systems for farm management receive much attention in the literature. One example is the AgroDSS software, a cloud-decison toolbox proposed by Rupnik et al. 2019 [45] that uses farm data to simulate scenarios and generate management recommendations based on that data. However, despite the high potential and good availability, the acceptance in practice has been low so far [46,47].

SF technologies can also support agricultural consultation and compliance with legal management requirements. Farmers have the opportunity to better comply with environmental regulations, since, for example, limit exceedances during fertilizer application can be immediately detected and controlled by sensors, or the distance to water bodies or sensitive areas can be precisely maintained by GPS. On the other side, authorities are able to carry out monitoring more efficiently, even without a physical presence on the farm. This also supports the implementation of ecological incentive systems that reward farm management measures that go beyond minimum standards. For example, regular measurement of the carbon dioxide content in soils could be used to integrate farms into emissions trading in the future. Against this background, new opportunities arise, for example, for recording and assessing ecosystem states [48] and thus for identifying and quantifying ecosystem services.

Cross-cutting platform communication, both between farmers and with experts and external service providers, holds ecological potential. One example is the Smart-AKIS initiative, which provides a network on SF technologies designed for effective knowledge exchange between research, industry, and the farming community to disseminate directly applicable research as well as commercial solutions, capturing farmers' needs and innovative ideas [11]. Other platforms, such as the PLATEM multimedia platform, provide 
functions to control the smart application of water, fertilizer, and pesticides [49]. It also enables the sharing of experience and know-how through an exchange of information with other farmers, producers, and experts. In developing countries and remote regions, low-cost wireless sensor network platforms could connect farmers with experts, ensuring continuous advice, higher yields, less pesticide use, and greater environmental sustainability. Clasen [50] also emphasizes that digital marketplaces in particular help to increase efficiency by both reducing transaction costs and improving factor pairings so that more suitable machine pairings can be created, which means, for example, that tractors that are too large and therefore too expensive would be used less frequently for a particular field.

\subsection{Crop Rotation and Cultivation Planning}

The planning of crop rotation and cultivation has long-term economic and ecological effects. Standardizing crop rotations, types of crops, and cropping systems put a strain on ecosystems [48] and narrow crop rotations, especially with root crops such as maize, can lead to soil compaction as well as erosion and loss of humus [51]. Diverse crop rotations, on the other hand, have numerous ecological advantages, such as suppression of weeds, promoting natural pest control and increasing overall biodiversity [52]. In the second half of the 20th century, there has been a shift in agricultural strategies towards the cultivation of monoculture crops, which rely on high resource inputs, especially the use of synthetic fertilizers and pesticides [53]. Monoculture leads to pests and pathogens spreading rapidly throughout the field [54] and also contributes to humus depletion [55]. Notwithstanding these advantages, the cultivation of mixed crops and frequently changing crop rotation is not widespread in conventional agriculture due to lower yields.

SF can greatly simplify the move away from monoculture and the planning of diverse crop rotations. Appropriate advisory services or platforms for the exchange of know-how promote the implementation of ecological crop rotations, which can also lead to efficiency gains. Soil and yield potential maps are particularly suitable for promoting the cultivation of mixed crops, as is the use of autonomous swarm robots in the future. The creation of comprehensive yield maps is already offered by various companies [56]. With data from sensors and aerial photographs, the field can thus be divided into different spots and later managed with different crops and/or crop rotations [57]. In addition, smart farm management software is able to provide recommendations for implementation, considering local conditions. Autonomous robots will be able to sow, tend, and harvest crops at the point in the field where they find optimal values and synergy effects are maximized [43]. Smaller machine dimensions thus allow for greater crop diversity, and lanes for large machines would no longer be necessary. In addition, alternative crop production systems such as strip farming can be implemented, in which crops can achieve higher yields.

\subsection{Tillage and Sowing}

Soils and the biodiversity they contain are a key factor in securing agricultural yields in the long term [58]. Before sowing, agricultural soils are mostly tilled mechanically to create the best possible conditions. However, the consequence of intensive tillage is often the decomposition of humus and the associated release of carbon dioxide [51]. Machines used for this purpose emit greenhouse gases and are largely responsible for soil compaction.

Sensors attached to robots or machines can collect soil data to create soil density maps as a basis for site-specific soil cultivation with minimized interventions. Exemplary, sensors are applied for working depth regulation [59]. Gorucu et al. [60] found for cotton cultivation that precision tillage resulted in fuel savings of more than one third compared to a control field that was tilled conventionally. Comparable results were obtained by Whattoff et al. [61]. Soil analysis for depth control may also significantly reduce tillage intensity. Shamal et al. [62] used a sensor to classify the degree of soil compaction into three compaction classes, determining that only $4.8 \%$ of the field studied required aggressive tillage and approximately $34.8 \%$ of the field required only harrowing or surface loosening with a cultivator, i.e., reduced tillage. Simulations also illustrated significant reductions in 
energy consumption and carbon dioxide emissions compared to reduced and conventional tillage practices [62].

Using swarms of small-scale robots for seeding can prevent or minimize environmental damage caused by heavy machinery. Moreover, by recording the position of each individual seed, field maps can be created $[63,64]$ that can be used later, e.g., for pest control by autonomous unmanned aerial vehicles (UAVs). Site-specific seeding also enables variable seeding patterns and densities or different varieties to be applied, depending on the parameters on the respective piece of field which can increase productivity [38].

\subsection{Fertilizer Application}

Nitrogen is considered the most important and universal fertilizer, but it can cause considerable environmental damage. Nitrogen that is not absorbed by plants ends up as nitrate in the groundwater as well as in surface water and as ammonia and nitrous oxide in the air. Ammonia has a eutrophic effect, damages plants, can contribute to acidification, and is also responsible for the emission of greenhouse gases [52]. Nitrous oxide contributes to climate change and is significantly more potent than carbon dioxide. In addition, the application of urea fertilizer leads to the release of carbon dioxide [65]. In water bodies, excess nitrogen, as well as excess phosphorus caused by excessive fertilizer use, can result in strong algal growth, displacing other animals and plants [66].

SF can contribute to mitigating harmful environmental impacts of fertilizer application. Nutrient management systems are designed to ensure optimal fertilizer use through accurate demand calculations. Sensors on tractors, UAVs, or as handheld devices enable measurement of current crop nitrogen levels [67,68], for example, through soil sampling [69] or determination of chlorophyll content $[70,71]$ and real-time application according to demand. In combination with biomass maps generated by satellite or UAV data, fertilizer application maps can also be generated, enabling site-specific fertilization [72,73]. The development of nutrient management systems is well advanced and also promises economic benefits through higher yields.

The potential for fertilizer savings seems large and empirical studies confirm the positive environmental effects. Gianquinto et al. [74] determined the optimal fertilizer timing of rice, corn, and wheat using sensors, achieving average nitrogen reductions of 18 to $45 \%$ in three field experiments. Bökle et al. [75] demonstrated that digital control and geo-referenced documentation of manure application using sensors provided accurate information and enabled site-specific management in contrast to conventional documentation methods. In the field trial by Bijay-Singh et al. [76], the use of a nitrogen fertilizer management strategy based on optical sensors in India resulted in high wheat yields as well as high fertilizer efficiency. Stierli [70] calculates that agriculture in Switzerland could avoid nitrogen surpluses and thus $140 \mathrm{t}$ of nitrous oxide emissions annually through site-specific fertilization. In Germany, the principle of site-specific application of fertilizers has been successfully implemented in several pilot farms [77]. Wagner and Marz [78] were able to show that variable-rate site-specific fertilization was the only fertilization method that led to a significant improvement in the nutrient situation. Zhang et al. [79] achieved a fertilizer reduction of $29 \%$ with a yield increase of $33 \%$ in variable-rate fertilization of corn compared to conventional fertilizer application. Trials in fruit production also indicate great potential. Aggelopoulou et al. [80] were able to achieve a saving of $38 \%(49.4 \mathrm{~kg} / \mathrm{ha})$ with site-specific nitrogen fertilization. Some crops also achieve a qualitative improvement. For example, winter wheat that received site-specific nitrogen fertilization has higher quality and can thus provide economic incentives [81].

\subsection{Crop Protection}

\subsubsection{Herbicide Application}

The regulation of weeds is an essential part of agriculture. Increased use of herbicides in recent decades has led to accumulation in the ecosystem that is toxic to the vegetation $[82,83]$. Biodiversity is affected by herbicide use as non-target plants may be damaged 
or herbicide-resistant populations emerge that can be hardly controlled. Many herbicides also result in the direct and indirect destruction of pollinating insects [84]. Spray drift during application and leaching of chemical components into water bodies are problematic as well [83].

SF technologies can contribute to a significant reduction in herbicide use with the help of various technologies. Farm management systems already equipped with satellite imagery enable optimize demand calculation and site-specific application, so that herbicides are only applied to affected areas. Data collected by UAV-mounted sensors or cameras are even suitable for early weed detection in a variety of broad-row crops and have high spatial resolution [85]. Systems for weed mapping and site-specific weed control have already been commercialized and are marketed by several suppliers [85]. However, complex handling and high time requirement as well as the small time window for weed detection and control make a broad practical application difficult. In this regard, accurate weed population models [86-90] could help determine best possible timing for treatments or other measures.

The potential for herbicide savings based on site-specific weed control is large. Hamouz et al. [91] achieved savings of 15 to $100 \%$ for the same yield in a field trial with winter wheat based on weed frequency data and relevant treatment thresholds. Gerhards and Oebel [92] achieved herbicide use reductions of 19 to $20 \%$ for herbicides against specific weeds with site-specific application when growing winter canola and as much as 58 to $81 \%$ when growing winter cereals. Timmermann et al. [93] were able to consistently save 54\% of herbicides in a four-year trial using a GPS-controlled sprayer. For grass weed herbicides, the savings were: $90 \%$ in winter cereals, $78 \%$ in corn, and $36 \%$ in sugar beets. For broadleaf weed herbicides, savings were $60 \%$ in winter cereals, $11 \%$ in corn and $41 \%$ in sugar beets. In addition, in areas where weed density remained below the weed control threshold, flora and fauna were able to establish themselves largely undisturbed. Field studies on crucifer detection in winter wheat fields covering 2656 ha achieved comparable results [94]. For example, savings of 13 to $61 \%$ were achieved by using site-specific application maps. Berge et al. [95] calculated a potential herbicide savings of $85 \%$ through smart herbicide application for spring wheat, and savings of 6 to $81 \%$ are possible for winter wheat [96]. Castaldi et al. [97] used UAVs to collect data and variably applied herbicides to a corn field based on these data. As a result, herbicide savings were 14 to $39 \%$ compared to a uniform area-wide application. Nordmeyer [98] was also able to demonstrate that variable herbicide application results in ecological as well as economic benefits due to a reduction in the applied amount.

The use of robots for application promises further savings in the amount of herbicide required and a reduction in the energy demand of the application. Gonzalez-de-Soto et al. [37], for example, were able to show that considerable fuel reductions could be realized. Autonomous robots are able to detect weeds and subsequently spray herbicides precisely resulting in an average herbicide savings of $50 \%$ in trial series [99]. Self-learning devices that use spectral reflections to distinguish crops from weeds and achieve hit rates of up to $100 \%$ [100]. In addition to detecting weed density, UAVs are capable of applying herbicides up to five times faster than traditional machines [101].

In addition to variable-rate application, the type and composition of the herbicide are critical; some can be combined while others may not be used together. The appropriate mixture depends on many, site-specific factors, so decision support systems provide a good way to plan and implement individual herbicide applications. This prevents the use of standardized and non-site-specific mixtures that contain unnecessary components. The Danish project Crop Protection Online-Weeds is a system adapted to Denmark that uses user input on, among other things, weed species and growth rates to calculate solutions for field-specific herbicide applications [102].

An alternative option for reducing herbicide use is to return to mechanical, but now automated, weed control. Mechanical weed control has several advantages, such as conserving microbial activity, reduction in carbon dioxide emissions, and less runoff 
and leaching of nutrients [103]. Several agricultural machinery manufacturers already distribute autonomous electric robots equipped with various tools such as weed brushes, harrows, hoes or torsion springs. These robots will allow simultaneous reductions of input costs and labor and maybe of particular interest in countries with high labor costs.

\subsubsection{Insecticide and Fungicide Application}

Although lethal and sub-lethal effects of insecticides on pollinators have been demonstrated under controlled conditions significant knowledge gaps in assessing the effects of insecticides long-term under real-world conditions remain [104]. Besides non-target species impacts, insecticides also enter water, air, and soil via spray drift and leaching [105] and thus, insecticides are expected to be a major driver of biodiversity loss in agricultural landscapes [104]. For example, reducing populations of pollinator-relevant insects such as honeybees and bumblebees impoverishes plant diversity and deprives birds and mammals of food $[65,106]$. Accordingly, as is the case for herbicide application, target species may develop resistances that cause further problems [107]. In addition, there is evidence that insecticides are responsible for the deaths of birds [108] and fish by ingesting toxic substances through food [109]. Fungicides can have similar negative effects, but have been studied less frequently. For example, copper-based fungicides have adverse effects on soil organisms such as earthworms and can reduce soil fertility in the long term [110]. Other fungicides affect the health of honeybees [104] and increase the mortality of amphibians, insects and algae, and alter the oxygen content of water bodies [111].

The detection of fungi and insects by sensors or aerial photography is much more difficult than for weeds. Nevertheless, basically similar technologies such as demand assessment, composition, application as well as monitoring can be applied. Thus, identical benefits in terms of quantity savings and mitigation of soil compaction risk can be achieved. Dammer and Adamek [112] implemented a spray program with variable spray rate using a sensor-controlled field sprayer that determined the plant biomass of a heterogeneous winter wheat field in real time and also controlled the amount of insecticide applied based on these measurements. As a result, $13.4 \%$ of insecticides were saved, sparing the ladybug population, for example [112]. In addition, there is also the possibility of completely avoiding the application of certain insecticides for some pests. One example is the control of the European corn borer with the ichneumon wasp, the natural enemy of the pest. The wasp larvae are enclosed in small, residue-free capsules and distributed over the affected field with the help of a drone [72]. This method is already fully established in practice and is offered by various service providers.

If fungicides are applied at the correct time and at the appropriate plant location, yields can be increased by 1 to $6 \%$ in addition to reducing the quantity [43]. Early detection of fungal infections-so that only the affected sections of the field are treated and a spread is prevented-promises even higher cost savings and positive environmental effects. Special sensors equipped with cameras are able to detect fungal stress in a plant before it shows visible symptoms $[113,114]$. Successful experiments were conducted for fungal infestations of hazelnut kernels and red chili peppers [115]. Online platforms for the exchange of experience and the integration of decision support systems could provide an increasingly important role here in the future. Another example is the AgroDSS decision support system mentioned earlier. It helps farmers effectively plan insecticide applications according to the predicted population size of certain pest species or determine appropriate insecticides for the current developmental stage of the pest [45]. Increased pest management efficiency through low-cost technologies can also result in significant environmental effects, as global crop losses due to crop pests are 20 to $40 \%$ of annual production [1].

\subsection{Irrigation}

Agriculture is the world's largest consumer of water, and the proportion of arable land that can be irrigated artificially has increased from 13\% in 1970 to $21 \%$ in 2017 [116]. Irrigation of crops is a basic requirement for stable yields in many regions and in some 
countries, the proportion of groundwater used for agriculture is as high as 90\% [117]. With climate change demand is expected to further increase [117]. As a result of excessive abstraction from water bodies significant environmental damage occur such as wetland degradation or coast erosion [118].

The yield of a crop to be irrigated depends largely on the factors of irrigation timing and quantity and thus, site-specific irrigation can contribute to conserving water resources. The knowledge base for smart irrigation can be provided by decision support systems, which are already being used in practice in various variations [11]. Filed sensors or UAVs track data on soil moisture, temperature or rainfall and support site-specific irrigation planning $[119,120]$.

The execution of the irrigation targets can then be performed manually or also automated. For example, autonomous robots are able to measure the water content of corn plants and irrigate accordingly [121]. Using smart wireless sensors to monitor field conditions and automated sluices that control water flow can significantly increase efficiency of furrow irrigation [122]. Smart irrigation controller can control pivots, sprinkler machines, or drip irrigation systems via an app and sends irrigation recommendations to farmers based on real-time information. Another advantage of precise irrigation is the reduction in greenhouse gas emissions through lower energy consumption of pumps and by reducing the release of nitrous oxide from the soil [38].

Significant water savings from smart technologies can be demonstrated in humid regions where irrigation supplements rainfall [123]. However, SF can also contribute to savings in arid regions: Nahry et al. [124] were able to save $23.10 \%$ of water through precise water application in maize cultivation in Egypt compared to traditional cultivation. Thus, they were able to confirm the results of Al-Kufaishi et al. [125] that variable-rate water application leads to savings compared to uniform application. Dobbs et al. [126] achieved water savings of up to 75\% with sensor-based automatic irrigation. Zhai et al. [9] simulated an intelligent decision support system for peanut cultivation in arid regions. One of the goals of the model was to facilitate adaptation to climate change, for example, by integrating new parameters such as drought or heat tolerance of crops. As a result, the system's decisions were able to increase yields.

\subsection{Harvesting}

Harvesting is a crucial moment in agriculture, which often requires the use of large machines. Tractors and harvesters are largely responsible for environmental damages during harvesting, as they compact the soil and emit large amounts of greenhouse gases [37]. New technologies, such as harvesting robots, could minimize this risk, as they are significantly lighter than conventional large machines. However, autonomous harvesting in the field is extremely complex and no prototypes or technical-theoretical designs of robotic mowers are discussed in the literature up to now.

Despite these research gaps, an optimal use of machinery by calculating the shortest routes and avoiding double travel can save up to $50 \%$ of fuel and associated greenhouse gas emissions during harvest [36]. Modern harvesters with position sensors are able to calculate ideal cutting paths and can thus significantly reduce their operating time [127]. Automatic steering functions on combine harvesters, for example, lead to lower diesel consumption and an average reduction in air pollution of $0.6 \mathrm{t}$ per year [128].

\section{Risks of SF Technologies}

\subsection{Rebound Effects}

The term rebound effect goes back to the observation that increasing energy efficiency of electric devices does not lead to savings, but on the contrary to increasing consumption as, e.g., individual efficiency gains are overcompensated by an increase in energy devices [129]. To date, a few rebound effects in agriculture have been scientifically discussed, but the majority have not yet been empirically proven. For rebound effects in agriculture not only the change in energy consumption but also that of other input factors must be considered. 
We were able to identify three different types of rebound effects in scientific literature on arable farming: those that refer to the expansion of cultivated areas, those that refer to the increasing use of input factors and those that refer to an energy-related rebound.

Generally, the efficiency gains through applying SF technology may lead to an expansion of agriculture production, since higher yields and/or lower production costs will ultimately result in lower market prices, which may increase total demand for agricultural goods, in particular for renewable resources and bio-energy. Farmers thus may face an incentive to expand their production, potentially also to marginal lands where production is not affordable without SF technologies. Pellegrini and Fernández [130] showed that while technological improvements can potentially reduce the amount of arable land needed, they can also have the opposite effect in a largely open market.

SF technologies for fertilizer application may also bring along rebound effects. Schieffer and Dillon concluded in a model experiment that effective cost savings create incentives to increase fertilizer use [131]. According to Ahlefeld [114], there is also a risk of increasing intensity on heterogeneous fields, which could hardly be fertilized before. In addition, the increase in efficiency could contribute to farmers cultivating higher-value crops than before with regard to a desired profit maximization and thus increase fertilizer intensity overall [114].

Rebound effects from digital innovations in irrigation have often been studied as it seems particularly susceptible to rebound effects [132]. For example, Sears et al. [117] show that increasing irrigation efficiency can lead to an increase in water use by making it less expensive to irrigate marginal lands. Li and Zhao [133] as well as Pfeiffer and Lin [134] provide empirical evidence to support the assumption that farmers will plant more waterintensive crops due to increased efficiency or irrigate previously non-irrigated slopes in the future. Similar results are provided by Molle and Tanouti [135], who demonstrate that increased irrigation efficiency in Morocco has led to a shift to more water-intensive crops and to an expansion of cultivated land. Berbel and Mateos [136] identify this as the greatest rebound effect risk and state that only if there is a physical or institutional constraint on land expansion is there unlikely to be a significant increase in water use.

Farm management software, decision support systems or similar tools do involve an energy input for the operation of computers and servers. However, the resources required for this have not yet been tracked, so that a precise assessment is not yet possible. Paul et al. [125] did a review of case studies on factor inputs in agriculture and conclude that efficiency improvements generally lead to real reductions in resource use and estimate the direct rebound effects of increased energy efficiency to be relatively small [132]. It can therefore be assumed for the time being that the positive environmental effects achieved by $\mathrm{SF}$ technologies can exceed the negative consequences of increasing energy use. However, this conclusion should not lead to a general underestimation of rebound effects in agriculture, as this is a largely neglected area of research so far.

\subsection{Barriers}

\subsubsection{Technological Barriers}

Technological barriers pose a major risk to realizing the environmental benefits of SF. They either prevent implementation or create uncertainty, so that farmers are reluctant to adopt SF technologies. Based on our literature screening we identify three main categories of technology barriers namely data protection and data security, standardization, and infrastructure requirements.

Uncertainties regarding data protection and sovereignty represent a major reason for farmers' hesitation in adopting SF technologies [137,138]. Accordingly, the problem has also become the most frequently cited obstacle to acceptance in the literature [33]. The academic debate has also often addressed the issue of data sovereignty and autonomy [139-142]. The stakeholders concerned have recognized that mass collection and storage of data also means a risk of misuse and loss of data sovereignty of farmers. Moreover, not only agricultural data is collected, but also personal data. 
Another frequently studied barrier to acceptance is the incompatibility of data due to the diverse format specification of digital systems [33]. Manufacturer-independent software and hardware or platforms for data exchange like the ISOBUS protocol for tractorimplement connections represent ways to avoid monopoly positions and allow farmers to make individual choices. Reuter et al. [143] note that binding standards for the exchange of data also contribute to fail-safe agriculture by preventing dependencies on individual manufacturers or systems.

The third hurdle for SF technologies is the lack of adequate infrastructure [144]. European Union member states often lack basic infrastructure, such as access to high-speed internet connections [145]. However, nationwide mobile coverage, especially in rural areas, is the basic prerequisite for SF to function reliably. Many developing countries also do not have the necessary infrastructure to be able to realize the opportunities of digitization. However, the use of autonomous robots usually requires not only 5G technology but also a fiber optic network in rural areas [146], so their possible use is currently limited to a few areas.

\subsubsection{Socio-Economic Barriers}

In addition to the technological challenges mentioned above, a number of socioeconomic barriers to the implementation of SF are discussed in the scientific literature, albeit in a scattered and often less comprehensive manner. We summarize the available literature in three strands: business barriers due to the high investment costs of SF technologies, the risk of oligopolization of SF providers, and lack of knowledge on the part of farmers.

The establishment of SF technologies is often associated with high investment costs. In the surveys conducted by Kernecker et al. [26] and by Barnes et al. [147] on challenges for adoption of SF-challenges, high costs are the most frequently mentioned barrier. In particular it is expected that only large farms would benefit from SF technologies, because it is too costly for smallholders [11]. This assumption is underpinned by empirical observations that large farms are significantly more likely to adopt precision farming technologies [148].

Another risk for SF technologies is the growing market power of agricultural corporations [144]. Economies of scale are particularly significant due to the relevance of data volumes. In addition, mergers between software and agricultural technology companies are necessary in order to develop viable complete solutions. The global oligopoly in seed, agricultural machinery and pesticide production is currently expanding its market power, and the comprehensive solutions offered by large corporations mean that smaller companies have little chance of entering the market. For example, after the successful merger, Bayer-Monsanto (Leverkusen, Germany) owns 33\% of the market share in the seed sector, followed by Corteva Agriscience (Wilmington, NC, USA) with 21.3\% [149]. A similar trend is emerging among agricultural machinery companies. In the future, large corporations could force farmers to purchase certain products due to a lack of compatibility as well as their sheer market power, as non-manufacturer solutions are not compatible with existing technology [150].

Finally, lack of know-how and qualification of farmers may slow down the adoption of SF technologies. The survey conducted by Barnes et al. [31] found that advisory services on SF contribute more to the adoption of precision agriculture methods than financial incentives and lack of information is the third most frequently cited reason for non-adoption [31]. Farmers often do not have sufficient information about current $\mathrm{SF}$ technologies and do not have access to individualized advisory services [26]. Operating modern hard- and software poses major challenges for many farmers. New skills and abilities are required to apply and interpret the results of Big Data systems [144]. Higher levels of information can also reduce the perceived complexity of the adoption process [22]. Further, a lack of information and extension services means that farmers are uncertain about the economic consequences of adoption. Kernecker et al. [26] identified the profitability of technologies as a key factor for adoption, but it is difficult for farmers to assess this for new, cost-intensive technologies without support and experience. The fact that young and better-educated farmers are more 
inclined to implement precision agriculture technologies [22,148] highlights the need for external extension and training services for less-educated farmers.

\section{Discussion and Governance Implications}

SF as a field of research is rapidly evolving. Many terms are not uniformly defined and results of scientific studies are heavily dependent on the relevant context and thus up-scaling of results is dubious. No wonder legal regimes by authorities lag behind the rapid technical development and are rather reactionary than formative. Management requirements and subsidies, as regulated by the European Union's Common Agricultural Policy, have a strong influence on the further development of agriculture and could thus facilitate the introduction of SF technologies and ensure their positive environmental impact. Based on the results of the previous sections, we argue for a more pro-active role of the state in the regulation of SF technologies and derive the following concrete policy recommendations for action:

1. Counteracting rebound effects: Potential rebound effects must be identified, and their occurrence prevented. This requires investments and further support for longterm research projects. Subsequently, regulatory steps such as the regulation of land use, trade and consumption are required to prevent environmentally harmful intensification of production, for example through certification systems. Compliance with regulatory requirements must then be verified. An example of the need for regulatory measures is the prevention of rebound effects in irrigation by limiting the ability to expand the irrigated area.

2. Support education and training: The economic and environmental benefits of SF must be communicated to farmers both in practice and in theory. This also applies to the identified risks. To this end, the gap between science and practical users must be closed. Agricultural education is also of major relevance. Accordingly, SF should be part of agricultural education and studies so that uncertainties regarding the application are minimized and non-adoption due to a lack of know-how are counteracted. In addition, comprehensive and professional training and consulting services are necessary. These must have a high degree of topicality and should be offered by neutral institutions because independent advice is crucial to successfully reach and support farmers and to promote the adoption of precision farming methods [151].

3. Financial support and incentive systems: In order to avoid that ecologically beneficial technologies are not established due to high investment costs, targeted support measures, such as government subsidies or financing options, are necessary. So that smalland medium-sized farms are also able to take advantage of the potential of these systems, there is a need to promote technologies that are specifically adapted to the needs of small- and medium-sized farms. Broad implementation may subsequently lead to a reduction in costs. Appropriate premiums or non-financial incentive methods could also lead to voluntary acquisition. Another effective measure is to invest in technologies that would not be economically viable without financial subsidies, but which have a significant positive impact on the environment. This results in a welfare gain for society as a whole. In the medium term, mandatory measures are also conceivable, such as the mandatory use of fertilizer application cards or the use of certain sensors that provide information on fertilizer activity and serve to (digitally) verify compliance with limit values. Ecologically positive results are thus rewarded, and limit value transgressions are sanctioned. This also allows more flexibility in setting limit values. Finger et al. [152] suggest that agri-environmental policy instruments be designed so that taxes, quotas, and subsidies target defined levels of agri-chemical inputs or polluting residues. Finally, the use of special certification systems also appears to be potentially expedient here, in that they contribute to transparent information regarding certain quality characteristics along the entire value chain. 
4. Implementation of binding standards: Further legal regulations on the collection, storage and transfer of other data are long overdue and must close the gaps that still exist. In addition, the expansion of security concepts and regulations on the use of decentralized networks and similar measures is the basic prerequisite for a fail-safe agricultural sector. In order to prevent farmers from becoming undesirably dependent on manufacturers and individual systems, mandatory standards must also be defined for software and hardware so that cross-platform compatibility can be guaranteed. The ISOBUS protocol for the tractor-implement connection can be mentioned as a model for such standards. Finally, the establishment or expansion of infrastructure, especially comprehensive mobile communications coverage in rural areas, is a relevant factor in ensuring the functionality and usability of modern technologies. This also includes the simple and free availability of public data such as weather information or cadastral and soil maps in standardized formats by the respective authorities. However, there are often legal hurdles that prevent comprehensive utilization options. To this end, there is also a need to expand the options for digital data transfer between authorities and farmers. In this regard, the handling of data from the European Union's Galileo satellite navigation system, in which data is collected and released via an interface, can be cited as a prime example [11]. The establishment of an agricultural master platform is therefore a promising measure that has the potential to minimize numerous obstacles and risks in a bundled manner as a neutral hub.

\section{Conclusions}

It was shown that SF technologies available today and those to come offer lots of opportunities to make arable farming more environmentally friendly while maintaining or increasing yields. In particular, the efficient use of fertilizers and pesticides can significantly minimize environmental impacts, primarily through demand-based application. The future use of robots for automated mechanical weed control may even lead to a complete avoidance of herbicide applications. Other potentials for increasing efficiency that are independent of the work steps are offered by the field mapping using GPS, UAVs and/or sensors, the use of farm management software and cross-functional platforms.

However, our analysis of risks of and challenges for SF technologies has made clear that these positive effects can be compromised by possible rebound effects in the process. These have hardly been part of the scientific debate to date, but may contribute to the fact that increased efficiency ultimately leads to increased resource use. Irrigation technologies have been identified as particularly at risk, often leading to expansion of irrigated area or intensification of irrigation activities. To avoid rebound effects, further research is needed. Technological and socio-economic barriers that prevent or slow down the diffusion of ecologically beneficial technologies were investigated as further risks. High investment costs and unresolved data protection issues in particular lead to non-adoption by farmers. To minimize the risks of SF, government institutions should avoid rebound effects, promote education, extension and training, provide financial support, create incentive systems, and establish binding technological standards.

Agricultural digitization does not represent an abrupt paradigm shift, but rather a continuously advancing process. This circumstance makes it difficult to specify concrete points in time when technologies will be market ready. Currently, farmers are increasingly using digital methods to collect and evaluate comprehensive data. Accordingly, the well-established precision farming methods that have been used for many years will be supplemented in the course of SF. In the medium to long term, it can be expected that autonomous, electrically powered tractors and, in particular, the use of swarm robotics will contribute to a significant change in farm management. In addition, intelligent networking of all agricultural production and value chains may hold further potential to minimize environmental impacts. 
Today, mostly large farms in industrialized nations are using SF technologies. In order to better realize the opportunities, diversified products and services must be available that go beyond a reduction in costs for input factors for large-scale farming. There is an important role for governments to play here, because even if a business case for SF is not clear yet, the environmental benefits of SF represent a welfare gain for society as a whole. Hence, government should take on a pro-active role in funding research on potential rebound effects of SF, providing the necessary infrastructure, closing the governance gaps with respect to data security and standardization as well as with regard to support consulting services on SF in particular to smallholder farms.

Author Contributions: Conceptualization, S.L. and C.S.-S.; formal analysis, S.L.; investigation, S.L.; methodology, S.L.; supervision, C.S.-S.; visualization, S.L.; writing-original draft, S.L. and C.S.-S. All authors have read and agreed to the published version of the manuscript.

Funding: This research received no external funding.

Institutional Review Board Statement: Not applicable.

Informed Consent Statement: Not applicable.

Data Availability Statement: Not applicable.

Conflicts of Interest: The authors declare no conflict of interest.

\section{References}

1. FAO. Cropland-Share in Land Area (\%). Available online: http://www.fao.org/faostat/en/\#data/EL (accessed on 13 June 2020).

2. Rudel, T.K.; Schneider, L.; Uriarte, M.; Turner, B.L.; DeFries, R.; Lawrence, D.; Geoghegan, J.; Hecht, S.; Ickowitz, A.; Lambin, E.F.; et al. Agricultural intensification and changes in cultivated areas, 1970-2005. Proc. Natl. Acad. Sci. USA 2009, 106, 20675-20680. [CrossRef]

3. Mandl, N.; Pinterits, M. Annual European Union Greenhouse Gas. Inventory 1990-2017 and Inventory Report 2019: Submission Under the United Nations Framework Convention on Climate Change and the Kyoto Protocol; European Environment Agency: Copenhagen, Denmark, 2019.

4. IPBES. Summary for Policymakers of the Global Assessment Report on Biodiversity and Ecosystem Services; IPBES secretariat: Bonn, Germany, 2019.

5. Change, I.P.C. Climate Change 2014: Mitigation of Climate Change; Cambridge University Press: Cambridge, UK, 2015; ISBN 978-1-107-05821-7.

6. Power, A.G. Ecosystem services and agriculture: Tradeoffs and synergies. Philos. Trans. R. Soc. B Biol. Sci. 2010, 365, $2959-2971$. [CrossRef]

7. Ma, R.; Zou, J.; Han, Z.; Yu, K.; Wu, S.; Li, Z.; Liu, S.; Niu, S.; Horwath, W.R.; Zhu-Barker, X. Global soil-derived ammonia emissions from agricultural nitrogen fertilizer application: A refinement based on regional and crop-specific emission factors. Glob. Chang. Biol. 2021, 27, 855-867. [CrossRef] [PubMed]

8. Raven, P.H.; Wagner, D.L. Agricultural intensification and climate change are rapidly decreasing insect biodiversity. Proc. Natl. Acad. Sci. USA 2021, 118. [CrossRef]

9. Zhai, Z.; Martínez, J.F.; Beltran, V.; Martínez, N.L. Decision support systems for agriculture 4.0: Survey and challenges. Comput. Electron. Agric. 2020, 170, 105256. [CrossRef]

10. Walter, A.; Finger, R.; Huber, R.; Buchmann, N. Opinion: Smart farming is key to developing sustainable agriculture. Proc. Natl. Acad. Sci. USA 2017, 114, 6148-6150. [CrossRef]

11. Bacco, M.; Barsocchi, P.; Ferro, E.; Gotta, A.; Ruggeri, M. The Digitisation of Agriculture: A Survey of Research Activities on Smart Farming. Array 2019, 3, 100009. [CrossRef]

12. Mulla, D.J. Twenty five years of remote sensing in precision agriculture: Key advances and remaining knowledge gaps. Biosyst. Eng. 2013, 114, 358-371. [CrossRef]

13. Klerkx, L.; Jakku, E.; Labarthe, P. A review of social science on digital agriculture, smart farming and agriculture 4.0: New contributions and a future research agenda. NJAS Wagening. J. Life Sci. 2019, 90, 100315. [CrossRef]

14. Frankelius, P.; Norrman, C.; Johansen, K. Agricultural Innovation and the Role of Institutions: Lessons from the Game of Drones. J. Agric. Environ. Ethics 2019, 32, 681-707. [CrossRef]

15. Alfred, R.; Obit, J.H.; Yee, C.C.P.; Haviluddin, H.; Lim, Y. Towards Paddy Rice Smart Farming: A Review on Big Data, Machine Learning and Rice Production Tasks. IEEE Access 2021, 9, 50358-50380. [CrossRef]

16. Lajoie-O'Malley, A.; Bronson, K.; van der Burg, S.; Klerkx, L. The future (s) of digital agriculture and sustainable food systems: An analysis of high-level policy documents. Ecosyst. Serv. 2020, 45, 101183. [CrossRef] 
17. Zaballos, A.G.; Rodriguez, E.I.; Adamowicz, A. The Impact of Digital Infrastructure on the Sustainable Development Goals: A Study for Selected Latin American and Caribbean Countries. Available online: https://publications.iadb.org/en/impact-digitalinfrastructure-sustainable-development-goals-study-selected-latin-american-and (accessed on 27 May 2021).

18. OECD. Digital Opportunities for Better Agricultural Policies; OECD: Paris, France, 2019.

19. Villa-Henriksen, A.; Edwards, G.T.; Pesonen, L.A.; Green, O.; Sørensen, C.A.G. Internet of Things in arable farming: Implementation, applications, challenges and potential. Biosyst. Eng. 2020, 191, 60-84. [CrossRef]

20. DOE. In Technology Readiness Assessment Guide; U.S. Department of Energy: Washington, DC, USA, 2009.

21. Wiseman, L.; Sanderson, J.; Zhang, A.; Jakku, E. Farmers and their data: An examination of farmers' reluctance to share their data through the lens of the laws impacting smart farming. NJAS Wagening. J. Life Sci. 2019, 90-91, 100301. [CrossRef]

22. Vecchio, Y.; Agnusdei, G.P.; Miglietta, P.P.; Capitanio, F. Adoption of Precision Farming Tools: The Case of Italian Farmers. Int. J. Environ. Res. Public Health 2020, 17, 869. [CrossRef] [PubMed]

23. Reichardt, M.; Jurgens, C.; Klöble, U.; Hüter, J.; Moser, K. Dissemination of precision farming in Germany: Acceptance, adoption, obstacles, knowledge transfer and training activities. Precis. Agric. 2009, 10, 525-545. [CrossRef]

24. Balogh, P.; Bujdos, Á.; Czibere, I.; Fodor, L.; Gabnai, Z.; Kovách, I.; Nagy, J.; Bai, A. Main Motivational Factors of Farmers Adopting Precision Farming in Hungary. Agronomy 2020, 10, 610. [CrossRef]

25. Pivoto, D.; Barham, B.; Waquil, P.D.; Foguesatto, C.R.; Corte, V.F.D.; Zhang, D.; Talamini, E. Factors influencing the adoption of smart farming by Brazilian grain farmers. Int. Food Agribus. Manag. Rev. 2019, 22, 571-588. [CrossRef]

26. Kernecker, M.; Knierim, A.; Wurbs, A.; Kraus, T.; Borges, F. Experience versus expectation: Farmers' perceptions of smart farming technologies for cropping systems across Europe. Precis. Agric. 2020, 21, 34-50. [CrossRef]

27. Thoni, T.; Beck, S.; Borchers, M.; Förster, J.; Görl, K.; Hahn, A.; Mengis, N.; Stevenson, A.; Thrän, D. Deployment of Negative Emissions Technologies at the National Level: A Need for Holistic Feasibility Assessments. Front. Clim. 2020, 2. [CrossRef]

28. Schmidthuber, L.; Maresch, D.; Ginner, M. Disruptive Technologies and Abundance in The Service Sector-Toward A Refined Technology Acceptance Model. Technol. Forecast. Soc. Chang. 2020, 155, 119328. [CrossRef]

29. Tao, D.; Wang, T.; Wang, T.; Zhang, T.; Zhang, X.; Qu, X. A systematic review and meta-analysis of user acceptance of consumeroriented health information technologies. Comput. Hum. Behav. 2020, 104, 106147. [CrossRef]

30. Taherdoost, H. A review of technology acceptance and adoption models and theories. Procedia Manuf. 2018, 22, 960-967. [CrossRef]

31. Barnes, A.; Soto, I.; Eory, V.; Beck, B.; Balafoutis, A.; Sánchez, B.; Vangeyte, J.; Fountas, S.; van der Wal, T.; Gómez-Barbero, M. Exploring the adoption of precision agricultural technologies: A cross regional study of EU farmers. Land Use Policy 2019, 80, 163-174. [CrossRef]

32. Knierim, A.; Borges, F.; Kernecker, M.L.; Kraus, T.; Wurbs, A. What Drives Adoption of Smart Farming Technologies? Evidence from a Cross-Country Study. In Proceedings of the 13th European IFSA Symposium, Chania, Greece, 1-5 July 2018; International Farming Systems Association, Ed.; International Farming Systems Association (IFSA) Europe: Chania, Greece, 2018.

33. Schleicher, S.; Gandorfer, M. Digitalisierung in der Landwirtschaft: Eine Analyse der Akzeptanzhemmnisse. In Proceedings of the Informatik in der Land-, Forst- und Ernährungswirtschaft, Fokus: Digitale Marktplätze und Plattformen. GIL-Jahrestagung, Kiel, Germany, 26-27 February 2018; Ruckelshausen, A., Meyer-Aurich, A., Borchard, K., Hofacker, C., Loy, J.-P., Schwerdtfeger, R., Sundermeier, H.-H., Floto, H., Theuvsen, B., Eds.; Köllen: Bonn, Germany, 2018; pp. 203-206, ISBN 9783885796725.

34. Talking Fields. Available online: https:/ / www.talkingfields.de (accessed on 15 July 2020).

35. Bramley, R.G.V.; Ouzman, J. Farmer attitudes to the use of sensors and automation in fertilizer decision-making: Nitrogen fertilization in the Australian grains sector. Precis. Agric. 2019, 20, 157-175. [CrossRef]

36. Jensen, H.G.; Jacobsen, L.-B.; Pedersen, S.M.; Tavella, E. Socioeconomic impact of widespread adoption of precision farming and controlled traffic systems in Denmark. Precis. Agric. 2012, 13, 661-677. [CrossRef]

37. Gonzalez-De-Soto, M.; Emmi, L.; Garcia, I.; Gonzalez-De-Santos, P. Reducing fuel consumption in weed and pest control using robotic tractors. Comput. Electron. Agric. 2015, 114, 96-113. [CrossRef]

38. Balafoutis, A.; Beck, B.; Fountas, S.; Vangeyte, J.; Wal, T.V.D.; Soto, I.; Gómez-Barbero, M.; Barnes, A.; Eory, V. Precision Agriculture Technologies Positively Contributing to GHG Emissions Mitigation, Farm Productivity and Economics. Sustainability 2017, 9 , 1339. [CrossRef]

39. Uyttenbroeck, R.; Hatt, S.; Piqueray, J.; Paul, A.; Bodson, B.; Francis, F.; Monty, A. Creating Perennial Flower Strips: Think Functional! Agric. Agric. Sci. Procedia 2015, 6, 95-101. [CrossRef]

40. Campbell, A.J.; Wilby, A.; Sutton, P.; Wäckers, F.L. Do sown flower strips boost wild pollinator abundance and pollination services in a spring-flowering crop? A case study from UK cider apple orchards. Agric. Ecosyst. Environ. 2017, 239, 20-29. [CrossRef]

41. Campbell, A.J.; Wilby, A.; Sutton, P.; Wäckers, F. Getting More Power from Your Flowers: Multi-Functional Flower Strips Enhance Pollinators and Pest Control Agents in Apple Orchards. Insects 2017, 8, 101. [CrossRef] [PubMed]

42. Conesa-Muñoz, J.; Bengochea-Guevara, J.M.; Ribeiro, A. Path Planning to Minimise Distances and Recharging Instances for A Small Fleet of Vehicles in An Arable Field. In Proceedings of the Precision Agriculture 'Proceedings of the 9th European Conference on Precision Agriculture, Lleida, Spain, 7-11 July 2013; Stafford, J.V., Ed.; Wageningen Academic Publishers: Wageningen, The Netherlands, 2013; pp. 373-380, ISBN 9789086867783.

43. Gaus, C.-C.; Minßen, T.-F.; Urso, L.-M.; Witte, T.D.; Wegener, J. Mit Autonomen Landmaschinen Zu Neuen Pflanzenbausystemen. 2018. Available online: https://orgprints.org/32438/ (accessed on 28 August 2020). 
44. Hillerbrand, F.; Treiber, M.; Bauerdick, J.; Bernhardt, H. Robotik in der Außenwirtschaft: Entwicklungskonzepte und tendenzielle Einflussmöglichkeiten auf die Prozesssteuerung durch den Landwirt. In Informatik in der Land-, Forst- und Ernährungswirtschaft, Fokus: Digitalisierung für Landwirtschaftliche Betriebe in Kleinstrukturierten Regionen-Ein Widerspruch in Sich? In Proceedings of the GIL-Jahrestagung, Vienna, Austria, 18-19 February 2019; Meyer-Aurich, A., Gandorfer, M., Barta, N., Gronauer, A., Kantelhardt, J., Floto, H., Eds.; Köllen: Bonn, Germany, 2019; pp. 77-82. ISBN 978-3-88579-681-7.

45. Rupnik, R.; Kukar, M.; Vračar, P.; Košir, D.; Pevec, D.; Bosnić, Z. AgroDSS: A decision support system for agriculture and farming. Comput. Electron. Agric. 2019, 161, 260-271. [CrossRef]

46. Rose, D.C.; Sutherland, W.J.; Parker, C.; Lobley, M.; Winter, M.; Morris, C.; Twining, S.; Ffoulkes, C.; Amano, T.; Dicks, L. Decision support tools for agriculture: Towards effective design and delivery. Agric. Syst. 2016, 149, 165-174. [CrossRef]

47. Lindblom, J.; Lundström, C.; Ljung, M.; Jonsson, A. Promoting sustainable intensification in precision agriculture: Review of decision support systems development and strategies. Precis. Agric. 2017, 18, 309-331. [CrossRef]

48. German Environment Agency. Landwirtschaft Quo Vadis? Agrar-und Ernährungssysteme der Zukunft—Vielfalt gewähren, Handlungsrahmen Abstecken. Position der Kommission Landwirtschaft beim Umweltbundesamt (KLU). Available online: https:/ / www.umweltbundesamt.de/publikationen/agrar-ernaehrungssysteme-der-zukunftveroeffentlicht (accessed on 26 May 2021).

49. Baseca, C.C.; Sendra, S.; Lloret, J.; Tomas, J. A Smart Decision System for Digital Farming. Agronomy 2019, 9, 216. [CrossRef]

50. Clasen, M. Die Rolle Digitaler Marktplätze in einer vollständig selbstgesteuerten Landwirtschaft. In Proceedings of the Informatik in der Land-, Forst- und Ernährungswirtschaft, Fokus: Digitale Marktplätze und Plattformen. GIL-Jahrestagung, Kiel, Germany, 26-27 February 2018; Ruckelshausen, A., Meyer-Aurich, A., Borchard, K., Hofacker, C., Loy, J.-P., Schwerdtfeger, R., Sundermeier, H.-H., Floto, H., Theuvsen, B., Eds.; Köllen: Bonn, Germany, 2018; pp. 17-22, ISBN 9783885796725.

51. Heißenhuber, A.; Haber, W.; Krämer, C. “Umweltprobleme der Landwirtschaft"—Eine Bilanz: 30 Jahre SRU-Sondergutachten No. 28; Umweltbundesamt: Dessau-Roßlau, Germany, 2015; Available online: https://www.umweltbundesamt.de/publikationen/ umweltprobleme-in-der-landwirtschaft (accessed on 25 August 2020).

52. Feindt, P.H.; Krämer, C.; Früh-Müller, A.; Heißenhuber, A.; Pahl-Wostl, C.; Purnhagen, K.P.; Thomas, F.; van Bers, C.; Wolters, V. Ein Neuer Gesellschaftsvertrag für Eine Nachhaltige Landwirtschaft: Wege zu Einer Integrativen Politik für Den. Agrarsektor; Springer: Berlin/Heidelberg, Germany, 2019; ISBN 978-3-662-58655-6.

53. IPBES. Background to pollinators, pollination and food production. In The Assessment Report of the Intergovernmental Science-Policy Platform on Biodiversity and Ecosystem Services on Pollinators, Pollination and Food Production; Potts, S.G., Imperatriz-Fonseca, V.L., Ngo, H.T., Eds.; IPBES secretariat: Bonn, Germany, 2016; pp. 1-25.

54. Heberer, B. Chancen und Risiken der grünen Gentechnik. In Grüne Gentechnik: Hintergründe, Chancen und Risiken; Heberer, B., Ed.; Springer: Berlin/Heidelberg, Germany, 2015; pp. 21-28. ISBN 978-3-658-09392-1.

55. German Environment Agency. Daten zur Umwelt: Ausgabe Umwelt und Landwirtschaft. Available online: https://www. umweltbundesamt.de/publikationen/daten-zur-umwelt-2011 (accessed on 25 August 2020).

56. Noack, P.O. Einsatz von Multi- und Hyperspektralsensoren in der Landwirtschaft. In Publikationen der Deutschen Gesellschaft für Photogrammetrie, Fernerkundung und Geoinformation e.V., Photogrammetrie—Fernerkundung-Geoinformatik—Kartographie, Proceedings of the Wissenschaftlich-Technische Jahrestagung der DGPF und PFGK18-Tagung, Munich, Germany, 7-9 March 2018; Kersten, T.P., Gülch, E., Schiewe, J., Kolbe, T.H., Stilla, U., Eds.; Deutsche Gesellschaft für Photogrammetrie, Fernerkundung und Geoinformation e.V.: Munich, Germany, 2018; pp. 840-850.

57. Wegener, J.K.; Urso, L.-M.; Hörsten, D.V.; Minßen, T.-F.; Gaus, C.-C. Neue Pflanzenbausysteme Entwickeln-Welche Innovativen Techniken Werden Benötigt? Landtechnik 2017, 72, 91-100. [CrossRef]

58. Nielsen, U.N.; Wall, D.H.; Six, J. Soil Biodiversity and the Environment. Annu. Rev. Environ. Resour. 2015, 40, 63-90. [CrossRef]

59. Herlitzius, T.; Grosa, A.; Hengst, M.; Przybyla, M. Bodenbearbeitungstechnik. In Jahrbuch Agrartechnik 2019; Frerichs, L., Ed.; Institut für mobile Maschinen und Nutzfahrzeuge: Braunschweig, Germany, 2019; pp. 107-121.

60. Gorucu, S.; Khalilian, A.; Han, Y.J.; Dodd, R.B.; Keskin, M. Variable Depth Tillage Based on Geo-Referenced Soil Compaction Data in Coastal Plain Region. of South. Carolina; American Society of Agricultural and Biological Engineers: St. Joseph, MI, USA, 2011.

61. Whattoff, D.; Mouazen, A.; Waine, T. A multi sensor data fusion approach for creating variable depth tillage zones. Adv. Anim. Biosci. 2017, 8, 461-465. [CrossRef]

62. Shamal, S.A.M.; Alhwaimel, S.A.; Mouazen, A.M. Application of an on-line sensor to map soil packing density for site specific cultivation. Soil Tillage Res. 2016, 162, 78-86. [CrossRef]

63. Blender, T.; Buchner, T.; Fernandez, B.; Pichlmaier, B.; Schlegel, C. Managing a Mobile Agricultural Robot Swarm for a seeding task. In Proceedings of the 42nd Annual Conference of the IEEE Industrial Electronics Society, Florence, Italy, 23-26 October 2016; Industrial Electronics Society, Ed.; Institute of Electrical and Electronics Engineers: Piscataway Township, USA, 2016; pp. 6879-6886.

64. Schwich, S.; Stasewitsch, I.; Fricke, M.; Schattenberg, J. Übersicht zur Feld-Robotik in der Landtechnik. In Jahrbuch Agrartechnik 2018; Frerichs, L., Ed.; Institut für mobile Maschinen und Nutzfahrzeug: Braunschweig, Germany, 2018.

65. Baumgarten, C.; Bilharz, M.; Döring, U.; Eisold, A.; Friedrich, B.; Frische, T.; Corinna Gather, C.; Günther, D.; Große Wichtrup, W.; Hofmeier, K.; et al. Umwelt und Landwirtschaft; Daten zur Umwelt. Available online: https://www.umweltbundesamt.de/ sites/default/files/medien/376/publikationen/uba_dzu2018_umwelt_und_landwirtschaft_web_bf_v7.pdf (accessed on 26 May 2021). 
66. Klages, S. Die neue Düngeverordnung; Bundesanstalt für Landwirtschaft und Ernährung: Bonn, Germany, 2018.

67. Hughes, M.; Mlambo, V.; Lallo, C.H.O.; Jennings, P.G.A. Optical chlorophyll measurements as predictors of total nitrogen, nitrogen fractions and in vitro ruminal nitrogen degradability in tropical grass forages. Afr. J. Range Forage Sci. 2016, 33, 253-264. [CrossRef]

68. Mazur, P.; Chojnacki, J. Comparison of two remote nitrogen up-take sensing methods to determine needs of nitrogen application. J. Agric. Eng. Res. 2017, 62, 76-79.

69. Padilla, F.M.; Farneselli, M.; Gianquinto, G.; Tei, F.; Thompson, R.B. Monitoring nitrogen status of vegetable crops and soils for optimal nitrogen management. Agric. Water Manag. 2020, 241, 106356. [CrossRef]

70. Stierli, P. Parzellenspezifische Düngung in Verbindung mit Smart/Precision Farming. Potenzialabschätzung der Treibhausgasreduktion durch parzellenspezifische Düngung in Verbindung mit Smart/Precision Farming, Bern, Switzerland. Available online: https:/ / www.agrocleantech.ch/images/Fachleute/Wissen/Parzellenspezifische-Dngung-mit-Smart-oder-PrecisionFarming.pdf (accessed on 13 April 2021).

71. Gabriel, J.L.; Zarco-Tejada, P.J.; López-Herrera, P.J.; Pérez-Martín, E.; Alonso-Ayuso, M.; Quemada, M. Airborne and ground level sensors for monitoring nitrogen status in a maize crop. Biosyst. Eng. 2017, 160, 124-133. [CrossRef]

72. Lutz, K.J. Digitalisierung der Landwirtschaft: Revolution mit evolutionärem Charakter. In CSR und Digitalisierung: Der Digitale Wandel als Chance und Herausforderung für Wirtschaft und Gesellschaft; Hildebrandt, A., Landhäußer, W., Eds.; Springer: Berlin/Heidelberg, Germany, 2017; pp. 429-442. ISBN 978-3-662-53202-7.

73. Siruvoru, V.; Vijay Kumar, N. Cloud Robotics in Agriculture Automation. In Proceedings of the New Trends in Computational Vision and Bio-Inspired Computing, Selected Works Presented at the ICCVBIC, Coimbatore, India, 29-30 November 2018; Smys, S., Iliyasu, A.M., Bestak, R., Shi, F., Eds.; Springer: Berlin/Heidelberg, Germany, 2020; pp. 1073-1086, ISBN 978-3-030-41862-5.

74. Gianquinto, G.; Sambo, P.; Orsini, F.; Sciortino, M.; Forte, V. Optical Tools, a Suitable Means to Reduce Nitrogen Use in Fertigated Tomato Crop. HortScience 2006, 41, 982. [CrossRef]

75. Bökle, S.; Reiser, D.; Griepentrog, H.W. Automatisierte und digitale Dokumentation der Applikation organischer Düngemittel. In Informatik in der Land-, Forst- und Ernährungswirtschaft, Fokus: Digitalisierung für Mensch, Umwelt und Tier, Proceedings of the GIL-Jahrestagung, Freising, Germany, 17-18 February 2015; Gandorfer, M., Meyer-Aurich, A., Bernhardt, H., Maidl, F.X., Fröhlich, G., Floto, H., Eds.; Köllen: Bonn, Germany, 2020; pp. 37-42. ISBN 978-3-88579-693-0.

76. Thind, H.S.; Kumar, A.; Choudhary, O.P.; Gupta, R.K.; Vashistha, M. Site-Specific Fertilizer Nitrogen Management Using Optical Sensor in Irrigated Wheat in the Northwestern India. Agric. Res. 2017, 6, 159-168. [CrossRef]

77. Speckle, J.; Angermair, W.; Brohmeyer, F.; Brüggemann, L.; Spicker, A.; Pauli, S.A. Teilflächenspezifische Düngung als Reaktion auf wachsende gesellschaftliche Anforderungen und als Beitrag zur Entspannung des Widerspruches zwischen Ökonomie und Ökologie. In Informatik in der Land-, Forst- und Ernährungswirtschaft, Fokus: Digitalisierung für Mensch, Umwelt und Tier, Proceedings of GIL-Jahrestagung, Freising, Germany, 17-18 February 2015; Gandorfer, M., Meyer-Aurich, A., Bernhardt, H., Maidl, F.X., Fröhlich, G., Floto, H., Eds.; Köllen: Bonn, Germany, 2020; pp. 301-306. ISBN 978-3-88579-693-0.

78. Wagner, P.; Marz, M. Precision Farming-Langzeitversuche mit Grunddüngungsstrategien. In Proceedings of the Informatik in der Land-, Forst- und Ernährungswirtschaft, Fokus: Digitale Transformation-Wege in eine zukunftsfähige Landwirtschaft. GILJahrestagung, Dresden, Germany, 6-7 March 2017; Ruckelshausen, A., Meyer-Aurich, A., Lentz, W., Theuvsen, B., Ruckelshausen, A., Eds.; Gesellschaft für Informatik: Bonn, Germany, 2017; pp. 157-160, ISBN 978-3-88579-662-6.

79. Zhang, S.; Lan, Y.; Li, W.; Hoffmann, W.C.; Xu, Y.; Ma, C.; Zhang, S.; Lan, Y.; LI, W.; Hoffmann, W.C.; et al. Variable Rate Fertilization for Maize and its Effects Based on the Site-Specific Soil Fertility and Yield No. 2. Available online: https: / / elibrary.asabe.org/abstract.asp?aid=23652 (accessed on 18 April 2021).

80. Aggelopoulou, K.D.; Pateras, D.; Fountas, S.; Gemtos, T.A.; Nanos, G.D. Soil spatial variability and site-specific fertilization maps in an apple orchard. Precis. Agric. 2010, 12, 118-129. [CrossRef]

81. Karatay, Y.N.; Meyer-Aurich, A.; Gandorfer, M. Ökonomik der teilflächenspezifischen N-Düngung von Weizen unter Berücksichtigung von Qualität, Risiko und N-Düngerestriktionen. In Proceedings of the Informatik in der Land-, Forst- und Ernährungswirtschaft, Fokus: Digitale Marktplätze und Plattformen. GIL-Jahrestagung, Kiel, Germany, 26-27 February 2018; Ruckelshausen, A., Meyer-Aurich, A., Borchard, K., Hofacker, C., Loy, J.-P., Schwerdtfeger, R., Sundermeier, H.-H., Floto, H., Theuvsen, B., Eds.; Köllen: Bonn, Germany, 2018; pp. 135-138, ISBN 9783885796725.

82. Singh, S.; Tiwari, S. Responses of plants to herbicides: Recent advances and future prospectives. In Plant Life Under Changing Environment: Responses and Management; Chauhan, D.K., Tripathi, D.K., Ramawat, N., Prasad, S.M., Sharma, S., Singh, V.P., Dubey, N.K., Eds.; Elsevier: Amsterdam, The Netherlands, 2020; pp. 237-250.

83. Van Bruggen, A.H.C.; He, M.M.; Shin, K.; Mai, V.; Jeong, K.C.; Finckh, M.R.; Morris, J.G. Environmental and health effects of the herbicide glyphosate. Sci. Total Environ. 2018, 616, 255-268. [CrossRef] [PubMed]

84. Sharma, A.; Jha, P.; Reddy, G.V.P. Multidimensional relationships of herbicides with insect-crop food webs. Sci. Total Environ. 2018, 643, 1522-1532. [CrossRef] [PubMed]

85. Fernández-Quintanilla, C.; Peña, J.M.; Andújar, D.; Dorado, J.; Ribeiro, A.; López-Granados, F. Is the current state of the art of weed monitoring suitable for site-specific weed management in arable crops? Weed Res. 2018, 58, 259-272. [CrossRef]

86. Dorado, J.; Sousa, E.; Calha, I.M.; González-Andújar, J.L.; Fernández-Quintanilla, C. Predicting weed emergence in maize crops under two contrasting climatic conditions. Weed Res. 2009, 49, 251-260. [CrossRef] 
87. Gonzalez-Andujar, J.L.; Chantre, G.R.; Morvillo, C.; Blanco, A.M.; Forcella, F. Predicting field weed emergence with empirical models and soft computing techniques. Weed Res. 2016, 56, 415-423. [CrossRef]

88. Royo-Esnal, A.; Torra, J.; Chantre, G.R. Weed Emergence Models. In Decision Support Systems for Weed Management, 1st ed.; Chantre, G.R., González-Andújar, J.L., Eds.; Springer: Berlin/Heidelberg, Germany, 2020; pp. 85-116. ISBN 978-3-030-44402-0.

89. Chantre, G.R.; Vigna, M.R.; Renzi, J.P.; Blanco, A.M. A flexible and practical approach for real-time weed emergence prediction based on Artificial Neural Networks. Biosyst. Eng. 2018, 170, 51-60. [CrossRef]

90. Renton, M.; Chauhan, B.S. Modelling crop-weed competition: Why, what, how and what lies ahead? Crop. Prot. 2017, 95, 101-108. [CrossRef]

91. Hamouz, P.; Hamouzová, K.; Holec, J.; Tyšer, L. Impact of site-specific weed management on herbicide savings and winter wheat yield. Plant. Soil Environ. 2013, 59, 101-107. [CrossRef]

92. Gerhards, R.; Oebel, H. Practical experiences with a system for site-specific weed control in arable crops using real-time image analysis and GPS-controlled patch spraying. Weed Res. 2006, 46, 185-193. [CrossRef]

93. Timmermann, C.; Gerhards, R.; Kühbauch, W. The Economic Impact of Site-Specific Weed Control. Precis. Agric. 2003, 4, 249-260. [CrossRef]

94. Castro, A.I.D.; López-Granados, F.; Jurado-Expósito, M. Broad-scale cruciferous weed patch classification in winter wheat using QuickBird imagery for in-season site-specific control. Precis. Agric. 2013, 14, 392-413. [CrossRef]

95. Berge, T.W.; Goldberg, S.; Kaspersen, K.; Netland, J. Towards machine vision based site-specific weed management in cereals. Comput. Electron. Agr. 2012, 81, 79-86. [CrossRef]

96. Schrijver, R. Precision Agriculture and the Future of Farming in Europe: Scientific Foresight Study. Available online: https: / / op.europa.eu/s/oQeH (accessed on 18 April 2021).

97. Castaldi, F.; Pelosi, F.; Pascucci, S.; Casa, R. Assessing the potential of images from unmanned aerial vehicles (UAV) to support herbicide patch spraying in maize. Precis. Agric. 2017, 18, 76-94. [CrossRef]

98. Nordmeyer, H. Herbicide Application in Precision Farming Based on Soil Organic Matter. J. Exp. Agric. Int. 2015, 8, 144-151. [CrossRef]

99. Ørum, J.E.; Kudsk, P.; Jensen, P.K. Economics of Site-Specific and Variable-Dose Herbicide Application. In Precision Agriculture: Technology and Economic Perspectives; Pedersen, S.M., Lind, K.M., Eds.; Springer: Berlin/Heidelberg, Germany, 2017; ISBN 978-3-319-68713-1.

100. Moshou, D.; Kateris, D.; Pantazi, X.-E.; Gravalos, I. Crop and weed species recognition based on hyperspectral sensing and active learning. In Precision Agriculture, Proceedings of the 9th European Conference on Precision Agriculture, Lleida, Spain, 7-11 July 2013; Stafford, J.V., Ed.; Wageningen Academic Publishers: Wageningen, The Netherlands, 2013; pp. 555-562. ISBN 9789086867783.

101. Ahmad, L.; Mahdi, S.S. Satellite Farming: An Information and Technology Based Agriculture; Springer: Berlin/Heidelberg, Germany, 2018; ISBN 978-3-030-03448-1.

102. Sønderskov, M.; Rydahl, P.; Bøjer, O.M.; Jensen, E.J.; Kudsk, P. Crop Protection Online-Weeds: A Case Study for Agricultural Decision Support Systems. In Real-World Decision Support Systems: Case Studies; Papathanasiou, J., Ploskas, N., Linden, I., Eds.; Springer: Berlin/Heidelberg, Germany, 2016; pp. 303-320. ISBN 9783319439167.

103. Peigné, J.; Ball, B.C.; Roger-Estrade, J.; David, C. Is conservation tillage suitable for organic farming? A review. Soil Use Manag. 2007, 23, 129-144. [CrossRef]

104. Kovács-Hostyánszki, A.; Li, J.; Pettis, J.; Settele, J.; Aneni, T.; Espíndola, A.; Kahono, S.; Szentgyörgyi, H.; Thompson, H.; Vanbergen, A.J.; et al. Chapter 2: Drivers of change of pollinators, pollination networks and pollination. In The Assessment Report of the Intergovernmental Science-Policy Platform on Biodiversity and Ecosystem Services on Pollinators, Pollination and Food Production; Potts, S.G., Imperatriz-Fonseca, V.L., Ngo, H.T., Eds.; IPBES secretariat: Bonn, Germany, 2016; pp. 27-149.

105. Hladik, M.L.; Main, A.R.; Goulson, D. Environmental Risks and Challenges Associated with Neonicotinoid Insecticides. Environ. Sci. Technol. 2018, 52, 3329-3335. [CrossRef] [PubMed]

106. Zaller, J.G. Insektensterben-Inwiefern Sind Pestizide Dafür Mitverantwortlich? No.27. Available online: https:/ /www.zobodat. at/pdf/ENTAU_0027_0285-0295.pdf (accessed on 31 April 2021).

107. Townsend, C.R.; Begon, M.; Harper, J.L. Nachhaltigkeit. In Ökologie, 2nd ed.; Townsend, C.R., Begon, M., Harper, J.L., Hoffmeister, T.S., Steidle, J.L.M., Thomas, F., Eds.; Springer: Berlin/Heidelberg, Germany, 2009; pp. 463-502. ISBN 978-3-540-95897-0.

108. Mineau, P. Direct Losses of Birds to Pesticides-Beginnings of a Quantification, No. 2. Available online: https://www.fs.fed.us / psw / publications/documents/psw_gtr191/psw_gtr191_1065-1070_mineau.pdf (accessed on 12 May 2021).

109. Ansari, M.S.; Moraiet, M.A.; Ahmad, S. Insecticides: Impact on the Environment and Human Health. In Environmental Deterioration and Human Health: Natural and Anthropogenic Determinants; Malik, A., Grohmann, E., Akhtar, R., Eds.; Springer Netherlands: Dordrecht, The Netherlands, 2014; pp. 99-123. ISBN 978-94-007-7890-0.

110. Wightwick, A.; Walters, R.; Allinson, G.; Reichman, S.; Menzies, N. Environmental Risks of Fungicides Used in Horticultural Production Systems. In Fungicides; Carisse, O., Ed.; INTECH Open Access Publisher: London, UK, 2010; pp. 272-304. ISBN 978-953-307-266-1.

111. McMahon, T.A.; Halstead, N.T.; Johnson, S.; Raffel, T.R.; Romansic, J.M.; Crumrine, P.W.; Rohr, J.R. Fungicide-Induced Declines of Freshwater Biodiversity Modify Ecosystem Functions and Services. Ecol. Lett. 2012, 15, 714-722. [CrossRef]

112. Dammer, K.-H.; Adamek, R. Sensor-Based Insecticide Spraying to Control Cereal Aphids and Preserve Lady Beetles. Agron. J. 2012, 104, 1694-1701. [CrossRef] 
113. Thiessen, E.; Heege, H.J. Site-Specific Sensing for Fungicide Spraying. In Precision in Crop Farming; Heege, H.J., Ed.; Springer: Dordrecht, The Netherlands, 2013; pp. 295-311. ISBN 978-94-007-6759-1.

114. Ahlefeld, P.J.W.V. Umweltschutz durch Präzisionslandwirtschaft-Sind Rebound-Effekte möglich? In Informatik in der Land-, Forst- und Ernährungswirtschaft, Fokus: Digitalisierung für Mensch, Umwelt und Tier, Proceedings of the GIL-Jahrestagung, Freising, Germany, 17-18 February 2015; Gandorfer, M., Meyer-Aurich, A., Bernhardt, H., Maidl, F.X., Fröhlich, G., Floto, H., Eds.; Köllen: Bonn, Germany, 2020; pp. 343-348. ISBN 978-3-88579-693-0.

115. Kalkan, H.; Beriat, P.; Yardimci, Y.; Pearson, T.C. Detection of contaminated hazelnuts and ground red chili pepper flakes by multispectral imaging. Comput. Electron. Agr. 2011, 77, 28-34. [CrossRef]

116. FAO. Land Area Equipped for Irrigation-Share in Cropland (\%). Available online: http://www.fao.org/faostat/en/\#data/EL (accessed on 15 June 2020).

117. Sears, L.; Caparelli, J.; Lee, C.; Pan, D.; Strandberg, G.; Vuu, L.; Lawell, L.C.-Y. Jevons' Paradox and Efficient Irrigation Technology. Sustainability 2018, 10, 1590. [CrossRef]

118. Mentaschi, L.; Vousdoukas, M.I.; Pekel, J.-F.; Voukouvalas, E.; Feyen, L. Global long-term observations of coastal erosion and accretion. Sci. Rep. 2018, 8, 12876. [CrossRef] [PubMed]

119. Meron, M.; Alchanatis, V.; Cohen, Y.; Tsipris, J. Aerial Thermography for Crop Stress Evaluation-A Look Into the State of the Technology. In Precision Agriculture, Proceedings of the 9th European Conference on Precision Agriculture, Lleida, Spain, 7-11 July 2013; Stafford, J.V., Ed.; Wageningen Academic Publishers: Wageningen, The Netherlands, 2013; pp. 177-183. ISBN 9789086867783.

120. Barbedo, J.G.A. A Review on the Use of Unmanned Aerial Vehicles and Imaging Sensors for Monitoring and Assessing Plant Stresses. Drones 2019, 3, 40. [CrossRef]

121. Linz, A.; Hertzberg, J.; Roters, J.; Ruckelshausen, A. "Digitale Zwillinge“ als Werkzeug für die Entwicklung von Feldrobotern in landwirtschaftlichen Prozessen. In Informatik in der Land-, Forst- und Ernährungswirtschaft, Fokus: Digitalisierung für Landwirtschaftliche Betriebe in Kleinstrukturierten Regionen-Ein Widerspruch in Sich? Proceedings of GIL-Jahrestagung, Vienna, Austria, 18-19 February 2019; Meyer-Aurich, A., Gandorfer, M., Barta, N., Gronauer, A., Kantelhardt, J., Floto, H., Eds.; Köllen: Bonn, Germany, 2019; pp. 125-130. ISBN 978-3-88579-681-7.

122. Uddin, J.; Smith, R.J.; Gillies, M.H.; Moller, P.; Robson, D. Smart Automated Furrow Irrigation of Cotton. J. Irrig. Drain. Eng. 2018, 144, 4018005. [CrossRef]

123. Dukes, M.D. Water Conservation Potential of Landscape Irrigation Smart Controllers. Trans. ASABE 2012, 55, 563-569. [CrossRef]

124. Nahry, A.E.; Ali, R.R.; Baroudy, A.E. An approach for precision farming under pivot irrigation system using remote sensing and GIS techniques. Agric. Water Manag. 2011, 98, 517-531. [CrossRef]

125. Al-Kufaishi, S.A.; Blackmore, B.S.; Sourell, H. The feasibility of using variable rate water application under a central pivot irrigation system. Irrig. Drain. Syst. 2006, 20, 317-327. [CrossRef]

126. Dobbs, N.A.; Migliaccio, K.W.; Li, Y.; Dukes, M.D.; Morgan, K.T. Evaluating irrigation applied and nitrogen leached using different smart irrigation technologies on bahiagrass (Paspalum notatum). Irrig. Sci. 2014, 32, 193-203. [CrossRef]

127. Hierzer, R. Prozessoptimierung 4.0: Den Digitalen Wandel als Chance Nutzen; Haufe Gruppe: Stuttgart, Germany, 2017; ISBN 9783648095195.

128. Savickas, D.; Steponavičius, D.; Kliopova, I.; Saldukaitè, L. Combine Harvester Fuel Consumption and Air Pollution Reduction. Water Air Soil Pollut. 2020, 231, 1-11. [CrossRef]

129. Berkhout, P.H.; Muskens, J.C.; Velthuijsen, J.W. Defining the rebound effect. Energy Policy 2000, 28, 425-432. [CrossRef]

130. Pellegrini, P.; Fernández, R.J. Crop intensification, land use, and on-farm energy-use efficiency during the worldwide spread of the green revolution. Proc. Natl. Acad. Sci. USA 2018, 115, 2335-2340. [CrossRef] [PubMed]

131. Schieffer, J.; Dillon, C. The economic and environmental impacts of precision agriculture and interactions with agro-environmental policy. Precis. Agric. 2015, 16, 46-61. [CrossRef]

132. Paul, C.; Techen, A.-K.; Robinson, J.S.; Helming, K. Rebound effects in agricultural land and soil management: Review and analytical framework. J. Clean. Prod. 2019, 227, 1054-1067. [CrossRef]

133. Li, H.; Zhao, J. Rebound Effects of New Irrigation Technologies: The Role of Water Rights. Am. J. Agric. Econ. 2018, 100, 786-808. [CrossRef]

134. Pfeiffer, L.; Lin, C.-Y.C. Does efficient irrigation technology lead to reduced groundwater extraction? Empirical evidence. J. Environ. Econ. Manag. 2014, 67, 189-208. [CrossRef]

135. Molle, F.; Tanouti, O. Squaring the circle: Agricultural intensification vs. water conservation in Morocco. Agric. Water Manag. 2017, 192, 170-179. [CrossRef]

136. Berbel, J.; Mateos, L. Does investment in irrigation technology necessarily generate rebound effects? A simulation analysis based on an agro-economic model. Agric. Syst. 2014, 128, 25-34. [CrossRef]

137. Vogel, P. Digitalisierung in der Landwirtschaft: Eine Analyse der Akzeptanzhemmnisse: Rechtliche Aspekte der Verfügungsbefugnis über Betriebsdaten und denkbare Regelungsansätze zur Stärkung der Datenhoheit. In Informatik in der Land-, Forstund Ernährungswirtschaft, Fokus: Digitalisierung für Mensch, Umwelt und Tier, Proceedings of the GIL-Jahrestagung, Freising, Germany, 17-18 February 2015; Gandorfer, M., Meyer-Aurich, A., Bernhardt, H., Maidl, F.X., Fröhlich, G., Floto, H., Eds.; Köllen: Bonn, Germany, 2020; pp. 331-336. ISBN 978-3-88579-693-0.

138. Regan, Á. 'Smart farming' in Ireland: A risk perception study with key governance actors. NJAS Wagening. J. Life Sci. 2019, 90, 100292. [CrossRef] 
139. Bronson, K. Looking through a responsible innovation lens at uneven engagements with digital farming. NJAS Wagening. J. Life Sci. 2019, 90-91, 100294. [CrossRef]

140. Rotz, S.; Duncan, E.; Small, M.; Botschner, J.; Dara, R.; Mosby, I.; Reed, M.; Fraser, E.D. The Politics of Digital Agricultural Technologies: A Preliminary Review. Sociol. Rural. 2019, 59, 203-229. [CrossRef]

141. Farooq, M.S.; Riaz, S.; Abid, A.; Abid, K.; Naeem, M.A. A Survey on the Role of IoT in Agriculture for the Implementation of Smart Farming. IEEE Access 2019, 7, 156237-156271. [CrossRef]

142. Rolandi, S.; Brunori, G.; Bacco, M.; Scotti, I. The Digitalization of Agriculture and Rural Areas: Towards a Taxonomy of the Impacts. Sustainability 2021, 13, 5172. [CrossRef]

143. Reuter, C.; Schneider, W.; Eberz, D. Resilient Smart Farming (RSF)—Nutzung digitaler Technologien in krisensicherer Infrastruktur. In Informatik in der Land-, Forst- und Ernährungswirtschaft, Fokus: Digitalisierung für landwirtschaftliche Betriebe in kleinstrukturierten Regionen-Ein Widerspruch in Sich? Proceedings of GIL-Jahrestagung, Vienna, Austria, 18-19 February 2019; Meyer-Aurich, A., Gandorfer, M., Barta, N., Gronauer, A., Kantelhardt, J., Floto, H., Eds.; Köllen: Bonn, Germany, 2019; pp. 177-182. ISBN 978-3-88579-681-7.

144. Jakku, E.; Taylor, B.; Fleming, A.; Mason, C.; Fielke, S.; Sounness, C.; Thorburn, P. "If they don't tell us what they do with it, why would we trust them?" Trust, transparency and benefit-sharing in Smart Farming. NJAS Wagening. J. Life Sci. 2019, 90-91, 100285. [CrossRef]

145. European Union. Declaration-A Smart and Sustainable Digital Future for European Agriculture and rural Areas. Available online: https:/ / smartagrihubs.eu/latest/news/2019/August/DD3Declarationonagricultureandruralareas-signedpdf-\%281 \%29.pdf (accessed on 1 August 2020).

146. Härtel, I. Agrar-Digitalrecht für eine nachhaltige Landwirtschaft 4.0. Natur Recht 2019, 41, 577-586. [CrossRef]

147. Barnes, A.P.; Soto, I.; Eory, V.; Beck, B.; Balafoutis, A.T.; Sanchez, B.; Vangeyte, J.; Fountas, S.; Wal, T.V.D.; Gómez-Barbero, M. Influencing incentives for precision agricultural technologies within European arable farming systems. Environ. Sci. Policy 2019, 93, 66-74. [CrossRef]

148. Paustian, M.; Theuvsen, L. Adoption of precision agriculture technologies by German crop farmers. Precis. Agric. 2017, 18, 701-716. [CrossRef]

149. Mooney, P. Blocking the Chain: Industrial Food Chain Concentration, Big Data Platforms and Food Sovereignty Solutions, Berlin, Germany. Available online: https://www.land-conflicts.fu-berlin.de/_media_design/Policy-Paper-Reihe/BlockingTheChain_ Englisch_web.pdf (accessed on 31 July 2020).

150. Verdonk, T. Planting the Seeds of Market Power: Digital Agriculture, Farmers' Autonomy, and the Role of Competition Policy. In Regulating New Technologies in Uncertain Times; Reins, L., Ed.; Springer: Berlin/Heidelberg, Germany, 2019; pp. 105-132. ISBN 978-94-6265-278-1.

151. EIP-AGRI Focus Group. EIP-AGRI Focus Group on Precision Farming: Final Report. Available online: https:/ / ec.europa.eu/eip/ agriculture/sites/agri-eip/files/eip-agri_focus_group_on_precision_farming_final_report_2015.pdf (accessed on 23 August 2020).

152. Finger, R.; Swinton, S.M.; El Benni, N.; Walter, A. Precision Farming at the Nexus of Agricultural Production and the Environment. Annu. Rev. Resour. Econ. 2019, 11, 313-335. [CrossRef] 